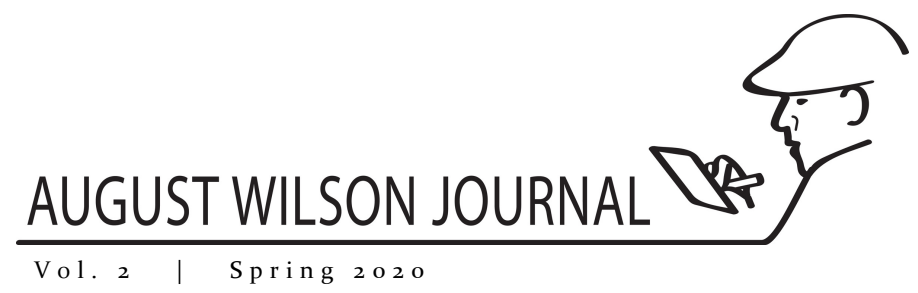

\title{
Stage Review of Matrix Theatre's Two Trains Running
}

\author{
Matrix Theatre; Los Angeles, California \\ March 1-3, 2019 \\ Directed by Michelle Shay \\ By David Román \\ Professor of English, American Studies, and Ethnicity, University of Southern California \\ In Shay's Two Trains Running, each of the actors brought to life their \\ character's multi-layered psychological intensity. \\ - David Román
}

\begin{abstract}
A review of Two Trains Running by August Wilson, staged at Matrix Theatre in Los Angeles, California from March 1 through March 3, 2019.

Keywords

Two Trains Running, August Wilson, plays, Sophina Brown, American Century Cycle

The actor and producer Sophina Brown plans to stage all ten plays of August Wilson's American Century Cycle in Los Angeles. Two Trains Running is her second production in this process, and it follows a critically and commercially successful run of King Hedley II at the Matrix Theatre in 2018. Brown intends to build a core audience that will be drawn to experience The Cycle in its entirety, all the while allowing audiences to experience each production individually and on its own terms. Brown has chosen not to stage the plays in succession either by the decade they represent or the order in which they were written.

Despite the recent revivals of Wilson's work at the Mark Taper Forum (Ma Rainey's Black Bottom, Joe Turner's Come and Gone) and the Pasadena Playhouse (Fences, Jitney), two of the premiere venues

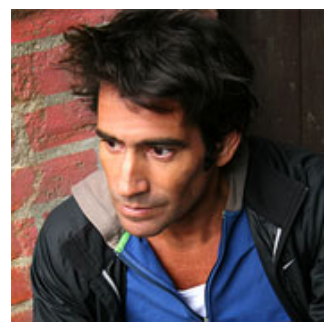

David Roman in the Los Angeles area, and the Fall 2019 Taper production of Ruben Santiago-Hudson's celebrated 2017 Broadway revival of Jitney and A Noise Within Theatre's Fall 2019 production of Gem of the Ocean, Brown sees a need to produce Wilson's American Century Cycle and feels that Los Angeles would appreciate her efforts. So far, she has been right. Both King Hedley II and Two Trains Running were hits, extending their initial limited runs and generating rave reviews from Los Angeles critics. The commitment to stage the cycle stems from Brown and not the theatre itself, which often partners with other artists to
\end{abstract}


present their work. It is Sophia Brown who will guide the cycle's completion in Los Angeles over the next several years.

One of the major differences between Brown's productions and those in mainstream venues is scale. The Matrix is a 99-seat theatre located in the center of Hollywood. It has a 4o-foot wide thrust stage that promotes an intimacy that is secured by the audience seating, which is only four aisles deep. Another major difference is access: tickets are reasonably priced and discounts for students, seniors, and groups are generous. Brown also does extensive community outreach to insure diverse audiences. All of this is to say that her audiences might not be the same audiences at the larger regional theatres producing Wilson's work concurrently. And while there is, of course, some overlap, there is enough interest in Wilson's work to allow for LA's theatres to develop unique audiences tailored to their mission and Wilson's place within it. That said, the Matrix production of Two Trains Running shared with these and other productions of Wilson's work over the years, and especially in the revivals since his death in 2005, a basic drive to honor Wilson's legacy by offering stagings steeped in naturalistic sets and costumes, and real, complex characterization. Everything is meant to service the historical plausibility of Wilson's dramaturgy.

Michelle Shay, a Wilson actor who received a Tony nomination for her performance in Seven Guitars, directed this production. (Shay also directed the 2018 Matrix production of King Hedley II.) Shay joins other prominent Wilson actors such as Ruben Santiago-Hudson and Phylicia Rashad who were also original cast members of Wilson's Broadway premieres to make the transition to directing his work. They are the immediate heirs to the playwright's canon, and their previous affiliations with his work credentialize them as directors of his plays. These directors (and some of their prominent colleagues such as Kenny Leon and Marion McClinton) follow the naturalistic impulses of Lloyd Richards, who set the standard for a Wilson production by casting strong actors working together as an ensemble to tell the specific story of the play. These "second-generation" Wilson directors---or post-Wilson directors---refuse any deliberate interpretation other than to serve as surrogates for Wilson's vision. The results are fully respectful and artistically sophisticated productions.

In Shay's Two Trains Running, each of the actors brought to life their character's multilayered psychological intensity. The production was designed to return us to Memphis Lee's Hill District Pittsburgh diner in 1969. While Memphis (Montae Russell) and Risa (Nija Okoro) remained the center of the play, the diner's regular customers never felt extraneous. Holloway, beautifully performed by Adolph Ward, rarely moved from his seat, as if his calming presence was a non-negotiable certainty in this period of social upheaval and change. Despite the actor's thinness and frailty, Holloway was monumental in his stature. While the other men busily moved in and out of Memphis's diner, Holloway and Risa did so less freely. He chose to sit; she was more constrained and tentative in her comings and goings. Risa's main movement was to and from the diner's kitchen, which was behind a counter that took up much of the stage. While the men moved readily in and out of the space, suggesting the emerging opportunities available to them in the late 196os despite the rampant systemic racism of the period, Risa literally could only step back. The only time she moved forward and closest to the audience-center stage, in fact-was to reveal the selfinflicted scars on her legs. In this one simple scene, Shay and Okoro stage Risa's entire character. Yes, she has a story, but it is hers and hers alone to tell even if the men already know if it.

John Iacovelli, a frequent Wilson scenic designer, created the meticulously historically accurate set. The set was composed of a period cigarette machine and jukebox, Art Decoinspired hanging light fixtures, a glass block placed over the diner's windows, red stools and diner tables, and most remarkably, a stunning wall of framed black and white photographs of historical Black figures who gained notoriety beginning in the 1950s, figures relevant and contemporary to the characters on stage. These images of Muhammad Ali, Nat King Cole, 
Ella Fitzgerald, and Martin Luther King among others-as well as those of local Pittsburgh personalities-conveyed the values of the community. The diner became the repository of this shared history, deepening Memphis' s claim of the property's value. These photographs provided Memphis and the others a visual archive of respectability and the evidence of its achievement. Rather than place the characters in contrast to these figures, Shay and Iacovelli embedded the actors portraying them in this iconic roster of pride. The actors performed the play sandwiched on the small Matrix stage between this wall of notable figures and the audience in the theatre. Whether it was through Black icons of sports, politics, and the arts of the 1950 overseeing the play's characters in 1969, or through the production itself promoting August Wilson as a figure deserving his own place on this portrait gallery of African American cultural heritage, the past was ever present as a marker of black resilience.

This reverence for the legacy of August Wilson-and that of Lloyd Richards, too-has resulted in beautifully nuanced productions of the ten-play cycle, including Sophina Brown's first-rate Matrix productions. And yet the political and artistic choice to stage naturalist interpretations of Wilson's work, while securing the playwright's canonical status, limits our idea of an August Wilson play. In staging realist authenticity, the productions run the risk of eventually appearing as costume dramas, conventional perhaps even predictable theatrical experiences.

Perhaps it is time to open up Wilson's spectacular achievement to a new generation of Black directors who excel in radical deconstruction and innovative theatricality. I am thinking of such accomplished directors as Robert O'Hara, Niegel Smith, Patricia McGregor, Kamilah Forbes, and Kwama Kwei-Armah, among many others, who are known for creating theatrical and innovative productions of new contemporary Black plays as well as American classics. I am not suggesting that we replace the traditional with something radically contrasting. Instead, why not indeed have two trains running----the local and the express, the conventional and the experimental-and invite twenty-first century artists and audiences along for the ride.

\section{Work Cited}

Wilson, August. Two Trains Running. The August Wilson Century Cycle. Theatre Communications Group. 2007.

\section{Author Bio}

David Roman is a professor of English and American studies at the University of Southern California. His research focuses on theatre and performance studies, American studies, Latina/o studies, and queer studies. 


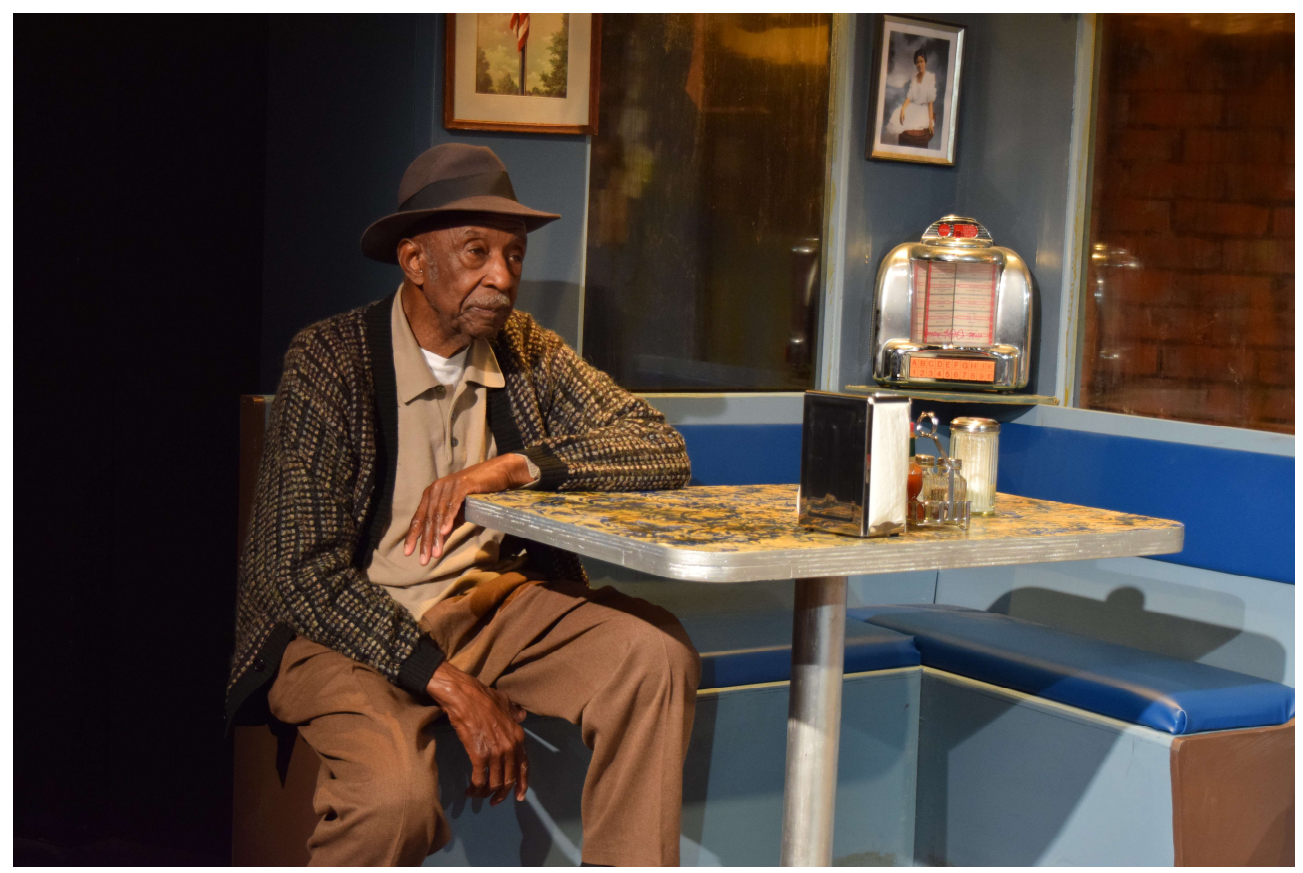

Adolphus Ward as Holloway

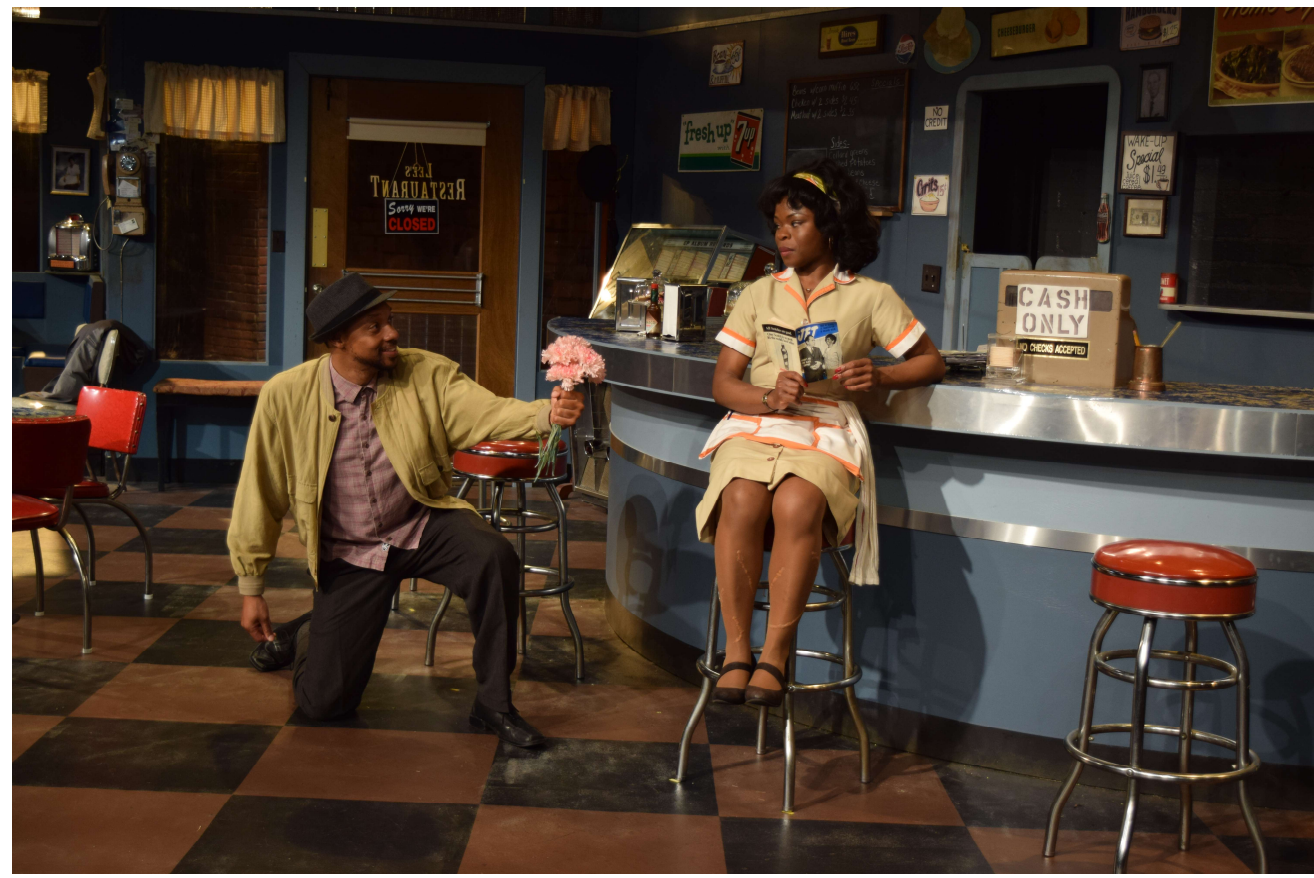

Dorian Missick and Nija Okoro as Sterling and Risa

All photos by Tiffany Judkins
(c) (7)
Articles in this journal are licensed under a Creative Commons Attribution 4.0 International License.
This journal is published by the University Library System of the University of Pittsburgh as part of its D-Scribe Digital Publishing Program and is cosponsored by the University of Pittsburgh Press. 